\title{
SONS VERSUS NEPHEWS: A HIGHLAND JAMBI ALLIANCE AT WAR WITH THE BRITISH EAST INDIA COMPANY, CA. 1800 Heinzpeter Znoj'
}

At the end of the eighteenth century, the southwest coast of Sumatra suddenly, and until today irreversibly, declined in importance in regional trade. First Penang, and later Singapore, with their free trade regimes, made the Straits of Malacca once again the dominant marketplace in Southeast Asia. This was the beginning of the end of British colonial enterprise in Sumatra, located as it was at a backwater of the new economic system. The highlands of Jambi, however, saw their economic and political role enhanced.

In this article I ask how this crucial shift in strategic location affected a region hitherto little considered in Sumatran historiography, namely the southern parts of highland Jambi. Luckily enough, a contemporary narrative provides insights into the regional politics and social upheavals during this historical watershed. It is a court drama which started at Muko-Muko on the west coast when the heir apparent of the Sultanate of Anak Sungai rebelled against his uncle, the Sultan, and which found its unspectacular end in the gold-mining area of Pangkalan Jambu in the eastern highlands. ${ }^{2}$ It deals with the desperate attempts of the British East India Company to

${ }^{1}$ Research for this article was made possible by a grant from the Swiss National Science Foundation and by the hospitality of the SEAP, Cornell University. I also wish to thank Prof. Oliver Wolters, Mary Steedly, Hugh Raffles, Kathrin Oester, Jeff Hadler, and Jürg Schneider for their thorough and generous comments on earlier versions of this article.

2 For locations see figure 1: "Map of Highland Jambi with selected villages ca. 1800." For the "cast" see figure 2: "Two versions of succession to the Sultanate of Anak Sungai." A note on spelling: I prefer 
control its business from the west coast at a time when money, people, and opportunities all moved to the east. It is fueled by the passions of a conflict over succession that ended with the abolition of matriliny in the Sultanate of Anak Sungai. And it confirms the astonishing fact that all important gold-mining settlements of central Sumatra, hitherto well-known as animist hotbeds, came under the control of reformist Islamic movements at the beginning of the nineteenth century. The analysis of these events provides some insights into the particular geography and form of highland Jambi resistance against the Dutch conquest a century later.

Little is known about the Jambi highlands before the twentieth century. We know much more about the coastal Sultanates to the east and west where the Europeans were stationed and which had been made relatively strong and stable by the trading arrangements with the European companies. In the interior, polities were more fragmented and less stable, but not necessarily less powerful during the rule of particular chiefs and their allies. ${ }^{3}$ The changeable polities of highland Jambi, as well as the biased chronicles of the Europeans on the coast, have in my opinion contributed to an underestimation of the role of the area in regional developments. Even if the importance of relations between the big Sultanates downstream and smaller polities upstream has been acknowledged in principle, ${ }^{4}$ the perspective in Sumatran historiography, with the exception of Minangkabau, remains largely focused on the downstream ports.

If compared to the history of Minangkabau relatively little is known of the history of the adjacent southern part of the central Sumatran highlands, this is due not simply to a lack of data, but also to the way the available data have been interpreted. Even if the British and Dutch, with posts restricted to the coast, did get information from the highlands, they were only minimally interested in the agency of the hill people themselves. In their minds, the highlands were the source of an unreliable flow of gold, and the locus of vast fallow lands awaiting colonial development. ${ }^{5}$ Highland politics, since there was no recognizable political center, were understood in terms of rebellion and anarchy. Even the identity of the inhabitants was hardly acknowledged, as they were described in more familiar terms, as Minangkabau mixed with "Palembangers" and Javanese. And if the term Kerinci was used, it tended to include the whole Jambi highlands, not the Kerinci valley proper. This colonial perspective continues to influence contemporary historiography, and it is the reason why the political landscape of the highlands at the period for which data begin to be available is still little understood. The pioneering works of Rapp on the strong highland federation along the Mesumai and Merangin under Pengeran Temenggung in the late nineteenth

\footnotetext{
modern standard Indonesian spelling for place names, for instance "Bengkulu" instead of "Bencoolen" or "Benkulen." I silently correct wrong transcriptions of place names that have made it into recent publications, like "Pangkalan Jambi" instead of "Pangkalan Jambu," or "Serampi" instead of "Serampas" or-in the local dialect-"Serampeih."

${ }^{3}$ Barbara Andaya, To Live as Brothers: Southeast Sumatra in the Seventeenth and Eighteenth Centuries (Honolulu: University of Hawaii Press, 1993), p. 89.

${ }^{4}$ Bennet Bronson, "Exchange at the upstream and downstream ends: notes toward a functional model of the coastal state in Southeast Asia," in Economic Exchange and Social Interaction in Southeast Asia, ed. Karl Hutterer (Ann Arbor: University of Michigan Press, 1977), pp. 39-54.

${ }^{5}$ C. M. Kan, De Nederlandsche Expeditie naar de Boven-Djambi en Korintji-Vallei (Utrecht: J. L. Beijers, 1876).
} 
century, ${ }^{6}$ Bill Watson on the history of village political structure in Kerinci, ${ }^{7}$ Hashim and Kathirithamby-Wells on the Sultanates of Indrapura and Muko-Muko on the west coast, $^{8}$ and Barbara Andaya on the gift-relationship between upstream and downstream polities in Jambi and Palembang ${ }^{9}$ provide us with a base on which to build.

The agents of the East India Company were particularly hampered by ignorance when it came to matriliny. Anak Sungai was the only area on the southwest coast under British control where the majority of the population, including the elite, was organized according to matrilineal principles. And as I will argue, the rebellion of the heir apparent of the Sultanate of Anak Sungai had one of its sources in a conflict over the validity of matrilineal succession. British sources referred to matrilineal inheritance in passing, but there is no evidence that they ever understood it clearly. Not even Marsden, the keen observer who wrote a chapter about the Minangkabau, mentions anything pertaining to their peculiar social structure. ${ }^{10}$ If later the notion of matriliny was to become the dominant paradigm in Minangkabau ethnography and historiography that would explain the working of local society, during the rule of the East India Company nothing like it was at hand. Manipulations of local politics by the servants of the EIC therefore remained anything but skillful. In taking sides in succession conflicts, officials of the EIC tended strongly to initiate patrilineal descent among the local elite, to the point of never formally acknowledging matrilineal succession. ${ }^{11}$ In fact, it is only in the 1860 s, when the "mother-right" had become an important issue in the evolutionary social theory of the day, that Dutch administrators started to understand more fully matriliny among the Minangkabau. But the British at the turn of the nineteenth century were not yet comfortable with the idea that within their territory rules of succession other than patrilineal ones should be recognized. It is therefore necessary to read the sources very critically as far as they represent kinship ties among the ruling elite, and thereby go a step further than scholars of the area have hitherto done.

\section{Highland Jambi at the Turn of the Nineteenth Century}

Two British sources and the Syair Mukomuko, a court chronicle from the early nineteenth century, bring to life the political landscape of highland Jambi at the turn of the nineteenth century. Hastings Dare's account of 1804-05 on a punitive expedition into Sungai Tenang and Serampas is well-known to us since it is in part reproduced in the third edition of Marsden's History of Sumatra. Barnes's account of a mission

${ }^{6} \mathrm{G}$. Ch. Rapp, Resultaten van het onderzoek in het gebied van den Pengeran Temenggoeng, (Jambi, 1931).

7 William C. Watson, Kerinci: Two Historical Studies, Occasional Paper No. 3 (Canterbury: Centre of SouthEast Asian Studies University of Kent at Canterbury, 1984).

${ }^{8}$ Muhammad Yussoff Hashim and Jeyamalar Kathirithamby-Wells, The Syair Mukomuko: Some Historical Aspects of a Nineteenth Century Sumatran Court Chronicle (Kuala Lumpur: MBRAS, 1977); Jeyamalar Kathirithamby-Wells, "The Inderapura Sultanate: The Foundations of its Rise and Decline, from the Sixteenth to the Eighteenth Centuries," in Indonesia 21 (April 1976): 63-84.

${ }^{9}$ Andaya, To Live as Brothers.

${ }^{10}$ William Marsden, The History of Sumatra (Singapore: Oxford University Press, 1986 [1811]), pp. 330-344.

11 Jeyamalar Kathirithamby-Wells, The British West Sumatran Presidency 1760-1785: Problems of Early Colonial Enterprise (Kuala Lumpur: Penerbit Universiti Malaya, 1977), pp. 40, 206. 
through Kerinci to Pangkalan Jambu in 1818 has been reprinted several times and recently been edited in full and annotated by Jeya Kathirithamby-Wells. ${ }^{12}$ Barnes's mission was ordered by Sir Thomas Stamford Raffles shortly after his return from his own famous journey to Minangkabau. The Syair Mukomuko, as well as the factory records of the British residency at Bengkulu, have equally been made available in recent years. ${ }^{13}$

In trying to understand religious developments, broader political structures and the trade networks of which these areas were part in the late eighteenth and early nineteenth centuries, I was struck how fragmented the southern Jambi highlands were in these respects. The breakdown of one trade route could throw a whole highland region into virtual isolation for decades. The southernmost parts of the highlands, for instance, drifted into marginality with the decline of the old gold-trading corridor linking the eastern foothills with the west coast. ${ }^{14}$ And the forests of the western slopes of the Barisan, long criss-crossed by footpaths and dotted with solid huts in which the itinerant traders spent the night, became almost totally deserted, with the result that today they are looked at as a refuge of untouched nature and have recently been declared a national park. But the opening up of new economic opportunities for the highlanders could trigger a period of fast cultural development and pressure for assimilation with the wider Malay culture. This history of stop-and-go-integration into wider social developments is typical for many highland areas of Southeast Asia. Even a seemingly marginal and isolated area may have lived through periods of intense contact, in- and outmigration, and mainstream cultural development. This is what may have happened in Kerinci, Sungai Tenang, and Serampas over a very long time.

Religion is one of the areas that sensitively register the ups and downs of integrative developments. At the beginning of the nineteenth century, a religious movement reformed daily life in parts of Kerinci and further downstream in Pangkalan Jambu in the same thorough way as the Wahhabi-inspired Padri movement did in Minangkabau. This fact is not yet well established among historians of the Padri movement in Sumatra, and I will argue for it in the last part of this article. The movement had a strong impact on later historical developments in the gold-mining areas and along the main trade routes in highland Jambi. How far, if at all, the influence of the Muslim reformers of the early nineteenth century reached south of Kerinci and Pangkalan Jambu into Serampas and Sungai Tenang is one of the questions I will address at the end of this article. The history of the "rebel" Sultanate in Pangkalan Jambu at the turn of the nineteenth century sheds enough light on this question to enable a tentative answer.

12 Jeyamalar Kathirithamby-Wells, Thomas Barnes' Expedition to Kerinci in 1818: Edited, Annotated and with an Introduction by J. Kathirithamby-Wells, Occasional Paper No. 7 (Canterbury: Centre of South-East Asian Studies University of Kent at Canterbury, 1986).

13 John Bastin, ed., The British in West-Sumatra (1685-1825) (Kuala Lumpur: University of Malaya Press, 1965); Hashim et al., The Syair Mukomuko.

14 My special interest in undertaking this historical foray as an anthropologist is to reconstruct the regional historical context of my own fieldwork area, Sungai Tenang and Serampas. I will address questions pertaining to this area in much greater detail in a forthcoming book. 


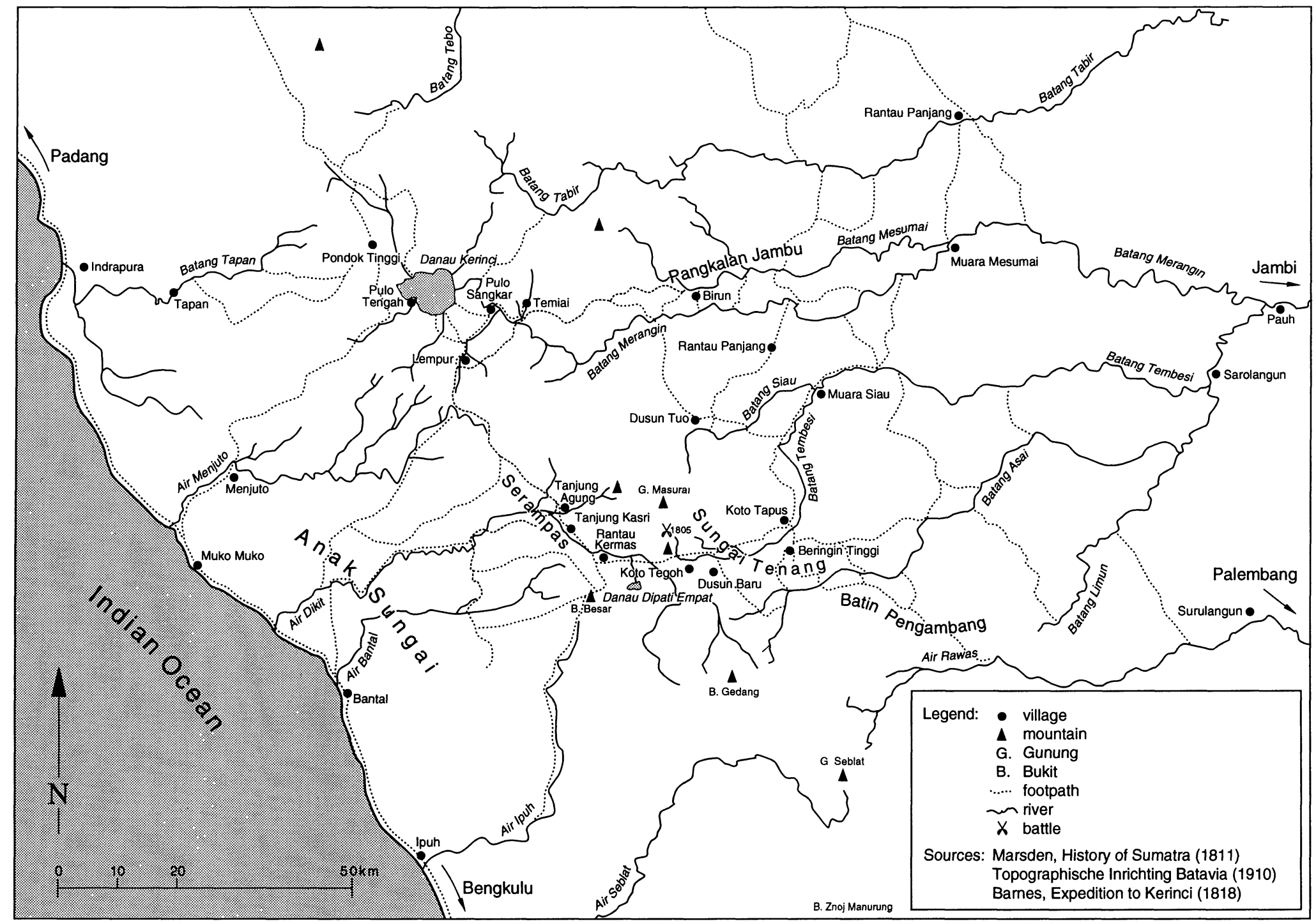

Figure 1: Map of Highland Jambi with selected villages ca. 1800 
102 Heinzpeter Znoj

\section{The Gold of Highland Jambi}

Barbara Andaya has vividly described how the eastern foothills of highland Jambi had become rich and powerful since the sixteenth century, due to the growing of pepper, and later, the panning and mining of gold. The area attracted many settlers, especially from Minangkabau, and the Sultans of Jambi were unable to exercise much control over this upstream area. ${ }^{15}$ Highland Jambi was to remain, due to massive immigration of miners from Minangkabau and peasants from the west coast, the most important source of gold in the whole of Sumatra until the end of the nineteenth century. ${ }^{16}$ This was part of an economic and political mobilization of the highlands that simultaneously engendered in Minangkabau the social and religious development so well described by Christine Dobbin. ${ }^{17}$ As a whole it contributed to the financial ruin of the pepper enterprises of the Dutch and British East India Companies on the west coast, which became at the time a mere hinterland in an economy oriented towards the Straits of Malakka. Yet even if it involved thousands of gold-miners and huge numbers of traders and peasants that supplied them, little is known about the polities that controlled highland Jambi's gold production. ${ }^{18}$

The southern highlands of Sumatra were a source of gold as important as Minangkabau. We know that gold was mined in Minangkabau by the second century $\mathrm{AD},{ }^{19}$ and there is evidence that gold mining in the southern parts of Sumatra goes back at least a thousand years. ${ }^{20}$ Together with the mines of Lebong, the highland Jambi gold mines were in all likelihood the sources of the gold of Srivijaya from the seventh through the fourteenth centuries. The highland Jambi gold mines must equally have been the major source of gold traded at the west coast port of Indrapura during the sixteenth and seventeenth centuries. Indrapura was known for its legendary gold mines in the seventeenth century, and before the Dutch arrived, it was an important port with links to Aceh. ${ }^{21}$ Close to the southern end of Lake Kerinci, a Lingga and Yoni stone monument ${ }^{22}$ testifies to the existence of a trade route from Pangkalan Jambu to the west coast at a time of strong Hindu influence, i.e. probably well before the fifteenth century. In the latter part of the nineteenth century the gold mines of Pangkalan Jambu, Batang Asai, and Limun in the Jambi highlands were the most

\footnotetext{
${ }^{15}$ Andaya, To Live as Brothers, pp. 151-52.

16 John N. Miksic, "Traditional Sumatran Trade," Bulletin - Ecole Française d'Extrème-Orient 74 (1985): 423-67, see especially pp. 451-2.

17 Christine Dobbin, Islamic Revivalism in a Changing Peasant Economy: Central Sumatra, 1784-1847 (London: Curzon Press, 1983).

18 Andaya, To Live as Brothers, pp. 151-53.

19 Dobbin, Islamic Revivalism, p. 176.

${ }^{20}$ John N. Miksic, Old Javanese Gold (Singapore: Ideation, 1990), p. 31; Simone Prodolliet and Heinzpeter Znoj, "Illusory World and Economic Realities: The Gold of Lebong," in The Rejang of Southern Sumatra, ed. Victor King (Hull: University of Hull Centre for Southeast Asian Studies, 1992), p. 60; Robert S. Wicks, Money, Markets, and Trade in Early Southeast Asia (Ithaca: Cornell Southeast Asia Program, 1992), p. 234.

${ }^{21}$ Kathirithamby-Wells, "The Inderapura Sultanate," p. 76.

22 Unreferenced information on highland Jambi is based on my own fieldwork carried out in 1989 and 1995-96.
} 
prolific of the whole of Sumatra, before the rubber boom of the early twentieth century virtually put an end to gold production there. ${ }^{23}$

To provide an idea of the magnitude of this production, a few numbers may suffice. Marsden notes that every year 600 ounces $(17 \mathrm{~kg})$ of gold reached Muko-Muko and 10,000 to 12,000 ounces (280-340 kg) reached Padang, while an equal amount was traded to the eastern parts of the island. ${ }^{24}$ British sources in the 1780 s estimated the annual exports from Padang at 200 to $240 \mathrm{~kg} .{ }^{25}$ Crawfurd estimated the total production of gold in Sumatra at $1,009 \mathrm{~kg}$ annually. ${ }^{26}$ Francis mentions for an unspecified time in the past, a time still under British rule, that 10,000 tahil of gold (400 $\mathrm{kg}$ ) used to reach Muko-Muko annually from Kerinci, ${ }^{27}$ Batang Asai, and Limun, and that it was exchanged mainly against opium. ${ }^{28}$ Perhaps this was during the rule of Sultan Pasisir Barat Syah (1752-1789) about whom the Syair Mukomuko says: "Selama baginda menjadi raja / terlalu ramai negeri Mukomuko / banyaklah dagang datang berniaga / menukar emas, apiun Benggala." ${ }^{29}$ The wide variation in the amounts of gold brought to Muko-Muko reflects the politics of gold trade in the interior and also the varying attractiveness of Muko-Muko as a market. Francis notes that in his own time (1833) the gold of highland Jambi was mainly traded to Padang. Since it is unlikely that gold from Minangkabau reached Muko-Muko in any quantity at any time, the $400 \mathrm{~kg}$ previously delivered to Muko-Muko annually must have come from highland Jambi alone. It is therefore a safe guess that highland Jambi produced in the magnitude of hundreds of kilograms of gold yearly during part of the eighteenth and nineteenth centuries. Considering the limited levels of technology and capital this compares rather favorably with the average yearly production of a little under two tons of the two biggest modern Dutch gold mines in Lebong that yielded about 70 percent of the Netherlands Indies' total gold production between 1897 and $1940 .^{30}$

\section{The "Rebellion" of Tuanku Mudo Zainal Abidin}

Anak Sungai was probably the most prolific pepper area on the Sumatran west coast during the seventeenth and eighteenth centuries. While it was still part of the Indrapura Sultanate, it was disputed first between Aceh and the Dutch, and later

\footnotetext{
23 O. L. Helfrich, "Bijdrage tot de kennis van Boven-Djambi," Tijdschrift van het Koninklijk Nederlandsch Aardrijkskundig Genootschap (1903-04), p. 992; J. Tidemann, Djambi (Amsterdam: Koninklyke Vereeniging "Koloniaal Institut," 1938), pp. 225-26.

24 William Marsden, The History of Sumatra, p. 168.

25 Kathirithamby-Wells, The British West Sumatran Presidency, pp. 175-77.

26 J. Crawfurd, History of the Indian Archipelago, vol. III (Edinburgh: Archibald Constable and Co., 1820), p. 486, quoted in Wolfgang Marschall, "Metallurgie und frühe Besiedelungsgeschichte Indonesiens," Ethnologica 4 (1968): 245.

27 Since there are no gold deposits of any importance in Kerinci itself, this very probably refers to the mines of Pangkalan Jambu.

28 E. A. Francis, "Benkoelen in 1833," in Tijdschrift voor Neêrlandsch-Indië IV,1 (1841): 417-450, esp. 427.

29 "For as long as His Majesty was in power, negeri Mukomuko was well populated. Many were the traders who came to barter gold for Bengal opium." Hashim et al., The Syair Mukomuko, canto v, pp. 48-49.

30 Prodolliet et al., "Mlusory Worlds," p. 69.
} 
between the Dutch and the British. ${ }^{31}$ Prolific as it was, Anak Sungai was also prone to fierce internal conflicts that repeatedly led to the breakdown of pepper production.

The rebellion of the heir apparent of the Sultanate of Anak Sungai, Tuanku Mudo Zainal Abidin, marks a critical phase not only for the Sultanate but also for the EIC (East India Company) west coast settlements and, ultimately, for the highland as well. The rebellion began in 1787 . Two years earlier, in 1785, the former West Sumatran presidency had been reduced to the status of a mere residency, which meant a severe reduction in finance and personnel. Pepper production had been in steady decline since the end of the 1770s, and many inhabitants moved from the coast to the highlands. The British enterprise never recovered. ${ }^{32}$

Tuanku Mudo Zainal Abidin had been brought up at Bengkulu under the tutelage of governor Roger Carter (1760-1767). Obviously the Company expected him to become a reliable partner in governing the Anak Sungai Sultanate. In 1779 he had been appointed Company pepper surveyor at Bantal, a job that should have helped to implement the EIC's system of forced cultivation and at the same time check the power of the "tyrannical" Sultan Pasisir Barat Syah. ${ }^{33}$ Zainal Abidin soon turned out to be an enterprising man, involving himself in the trade with the people from the interior. ${ }^{34} \mathrm{He}$ was so successful in promoting this trade that the local British agents, Peter Jack Cox in Muko-Muko and Richard Nevin in Bantal, complained sharply about the paucity of the private business they were able to make for themselves.

Their hatred for the heir apparent was so strong that Cox pulled down Zainal Abidin's house and Nevin denied him the resale of rice and salt. This occurred immediately before the "rebellion" of the heir apparent. It seems obvious therefore that the main conflict in the Sultanate was initially not one between the Sultan and his nephew (and would-be successor), but between the latter and the two Company servants. In a reversal of its favors, the Company turned to the old Sultan and pressed him to discipline the heir apparent. The Sultan duly asked his successor to perform a humiliating act of submission, namely to ceremonially scatter yellow rice, which was normally done by a female member of the court. Zainal Abidin refused and was disinherited in favor of the eldest son of the Sultan. ${ }^{35}$

Enraged by this and the actions of the British against him, Zainal Abidin planned to attack Muko-Muko, the capital of Anak Sungai, and forcibly claim the Sultanate. The British immediately sent a military force against him. After having Richard Nevin murdered and the Pasar at Bantal burnt down, Zainal Abidin escaped, carrying off the British agent of Ipuh, a certain Robert Leister. He held Leister hostage in Serampas between 1787 and 1789.

It is no wonder that an enterprising local ruler should try to dominate trade with the interior. When the EIC had taken control of the pepper trade, since the end of the seventeenth century, the local chiefs who had previously derived much of their income from the sale of pepper had been forced to look for alternative trading opportunities. They had found them invariably in the trade with people from outside

\footnotetext{
${ }^{31}$ Kathirithamby-Wells, "The Inderapura Sultanate."

32 Kathirithamby-Wells, The British West Sumatran Presidency.

${ }^{33}$ Ibid., pp. 94, 207.

${ }^{34}$ Hashim et al., The Syair Mukomuko, p. 17.

35 Ibid., p. 17.
} 
the control of the Company. An additional source of income for them was fines. And indeed, the Syair Muko-Muko denounces the Tuanku Mudo Zainal Abidin as a greedy collector of fines. ${ }^{36}$ These fines formed the basis of the trading capital he needed to attract sellers from the highlands. When the pepper trade declined, in the last quarter of the eighteenth century, ${ }^{37}$ the EIC was eager to get rid of such enterprising and successful trading chiefs and take the business with the highlands into their own hands.

Zainal Abidin's success as a trader rested on alliances with highland chiefs who were also to become his main allies during his subsequent campaign against the EIC. Probably already before the rebellion he had allied with the Pemuncak Pamanaka Sutan of Pangkalan Jambu and to that end arranged the Pemuncak's marriage with his own sister, Tenku Putri. ${ }^{38}$ The fact that Zainal Abidin's sister and his mother accompanied him on his escape to Serampas is evidence that such affinal ties indeed already existed and had to be protected. Such a close relationship to the chief of one of the most important sources of gold in the highlands made Zainal Abidin a potentially very powerful ruler at Muko-Muko, a ruler who might have had more leverage against the EIC than its representatives could tolerate.

Zainal Abidin's "rebellion" was thus no doubt at least partly a reaction to provocation by the EIC's local agents. In the immediate aftermath of his escape, he did not seem to have a clear idea of how to proceed. Initially he waited in Serampas for an opportunity to take over the Sultanate. Serampas was an obvious place to stay for him, since at this crossroads he was able to divert goods from the east on their way to Muko-Muko or Ipuh and thus build up pressure against the Sultan and the EIC. The British negotiated his return to the coast and even convinced the Sultan to reinstate him as heir apparent. But Zainal Abidin did not return, and at the same time his position deteriorated when he fell out with his Serampas hosts after killing two village chiefs (Depati) there. He and his followers had to move closer to the west coast again, to the Menjuto river, where the frustrating negotiations with the Company continued. Pressed by British troops, the party moved on to Indrapura, which was under Dutch control. The Sultanate of Indrapura had always tried to maintain some influence in questions of succession involving the Sultanate of Anak Sungai, which had separated from it in the course of a civil war in 1691. Perhaps Zainal Abidin tried there to mobilize support for his cause. But the Sultana of Indrapura refused her help, anxious to avoid trouble with the EIC. ${ }^{39}$

It may have been about at this time that Zainal Abidin changed his strategy, giving up his plans of becoming Sultan at Muko-Muko and instead setting his sights on Pangkalan Jambu, the home of his brother-in-law, Pemuncak Pamanaka Sutan. Instead of hoping to control the gold trade on the west coast, which was in decline due to the emerging competition of markets on the Straits of Malakka, it had now become Zainal Abidin's aim to take part in building a powerful polity around the gold mines of Pangkalan Jambu.

\footnotetext{
36 Ibid., p. 49, canto v/35.

${ }^{37}$ Kathirithamby-Wells, The British West Sumatran Presidency, p. 217.

${ }^{38}$ When they mention him for the first time about a year after Zainal Abidin's flight, the sources already call the Pemuncak the brother-in-law of the rebel. See Hashim et al., The Syair Mukomuko, p. 19.

${ }^{39}$ Hashim et al., The Syair Mukomuko, pp. 18-19.
} 
106 Heinzpeter Znoj

Indeed, the winds of change blew eastward at the time, and Zainal Abidin's trek to the eastern foothills is emblematic for the shift of fortunes from the west coast to the highlands and the Straits of Malacca that occurred at the time of his rebellion. Not only had the British West Sumatran possessions been reduced from their presidency status to that of a mere residency in 1785 , but a year later the East India Company founded a new residency at Penang to take advantage of the swiftly expanding private trade in the Straits, adding the pressure of competition to the loss of status for the agents at Sumatra's west coast.

Late in May, 1789, Zainal Abidin retreated from the Indrapura coast via Tapan to Pulau Sangkar in Kerinci. Eventually, his own mother, wife, and his eldest son, Sutan Si Kunda, who had stayed behind in Indrapura, returned to Muko-Muko, forced back by the Company. Only about a month after Zainal Abidin's departure to the highlands, the Sultan, his uncle, died in July 1789, but the nephew failed to show up to claim the title, preferring the prospects of a fresh start at Pangkalan Jambu to the difficult position he had maneuvered himself into vis-à-vis the British. In April 1790, an expedition led by Captain Hamilton and the Bugis under Daeng Ma'ruppa tracked down Zainal Abidin in Kerinci. He escaped while his mother, who had rejoined his party, was brought back to Muko-Muko. Zainal Abidin himself never tried again to repossess Anak Sungai.

\section{A Patrilinear Revolution}

The British sources, ${ }^{40}$ the Syair Mukomuko and the editors of the Syair all depict the conflict of succession of 1787-89 in the Sultanate of Anak Sungai as taking place within a single patrilineage. According to this version, the eldest son and heir apparent, Zainal Abidin, was replaced by a younger son, Tuan Sutan Takdirullah alias Sultan Khalifatullah Inayat Syah (see Figure 2: Two versions of succession to the Sultanate of Anak Sungai).

There are reasons to doubt this representation. I am convinced that the conflict was made all the more heated and protracted because it involved the deviation from the hitherto accepted rule of matrilineal succession to the title of Sultan of Anak Sungai. Such a breaking of the rules would have meant a revolution, because the local chiefs, the Menteri Empat Belas (the "fourteen Menteri"), would have lost their kinbased influence at the court in Muko-Muko. We know that Anak Sungai used to be a staunchly matrilinear Sultanate following the Bodi Caniago tradition of Minangkabau adat, where even the title of the Sultan was inherited by one of the Sultan's sororal nephews. ${ }^{41}$ Previously, also Indrapura to the north had had this system; patrilineal succession there was established in 1660 , at the occasion of Dutch assumption of control over the Sultanate. For the Dutch, dealing with a single patrilineal clan was far more efficient than dealing with a far-flung matrilinear kin-group that had more democratic notions of rule. ${ }^{42}$ The chiefs of Anak Sungai, then part of the Sultanate of Indrapura, vehemently opposed the new rules of succession. A long civil war ensued

\footnotetext{
40 See also Marsden, The History of Sumatra, p. 354; Richard Farmer, "Translation of the Undang Undang of Moco Moco," Malayan Miscellanies II No. XIII, p. 13.

41 Hashim et al., The Syair Mukomuko, p. 13; Kathirithamby-Wells, "The Inderapura Sultanate," pp. 73-74, 79-80.

${ }^{42}$ Kathirithamby-Wells, "The Inderapura Sultanate," p. 72.
} 


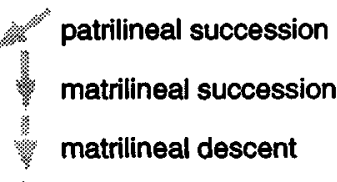

A official Sultan of Anak Sungai

A "rebel" Sultan of Anak Sungai

\section{Official Version}

--- Interruption of linear succession

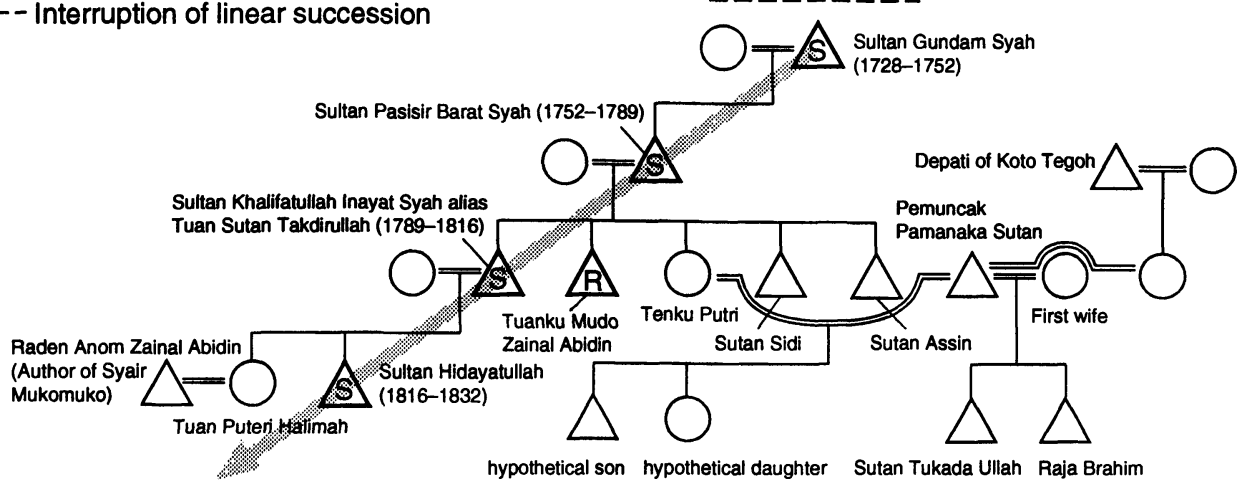

\section{Alternative}

"matrilineal" Version
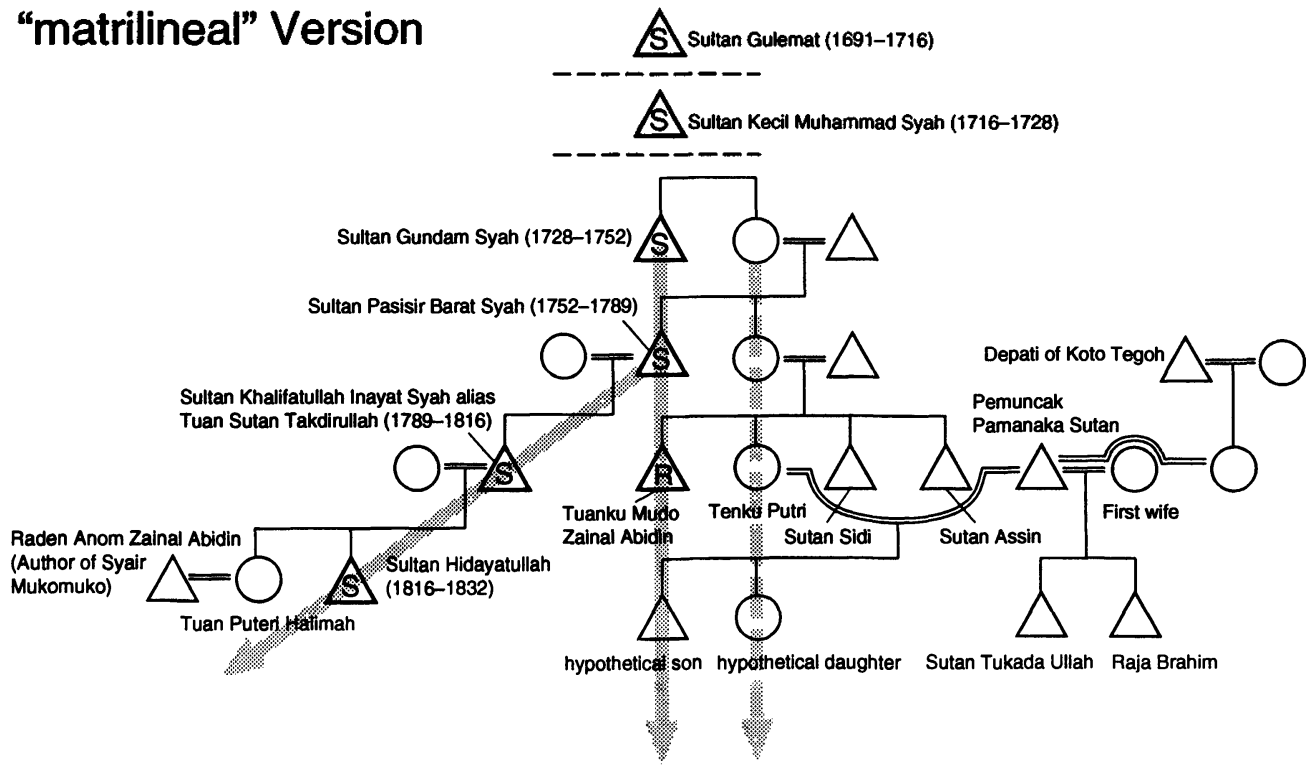

Figure 2: Two versions of succession to the Sultanate of Anak Sungai 
that led to the breakaway, with the help of the British East India Company, of Anak Sungai as a Sultanate independent of Indrapura. ${ }^{43}$ The Menteri Empat Belas had again to defend matrilinear succession to the Sultanate in 1728, when Sultan Kecil Muhammad Syah tried to make his own son his successor. They killed the Sultan and chose Merah Bangun alias Sultan Gundam Syah as successor. ${ }^{44}$ The British who, like the Dutch at Indrapura, would have preferred the more familiar and convenient patrilineal system, had to accept this.

According to the Syair Mukomuko, the successor of Sultan Gundam Syah was his own son, who ruled as Sultan Pasisir Barat Syah. ${ }^{45}$ If this were true, 1752 would have been the year of a patrilinear revolution, and the Menteri Empat Belas would finally have had to submit to the wishes of the British. The editors of the Syair do not address this important question, accepting the Syair's representation of a patrilinear succession in 1752, just as they accept its representation of the conflict over succession of 1787-89 as taking place within one patriclan. Given the history of Anak Sungai, one would expect a strong reaction by the Menteri on the occasion of this supposed first partilineal succession to the Sultanate, in 1752. But there is no evidence for this. The conflict of succession between Zainal Abidin and the Sultan thirty-five years later, however, is in the magnitude of the reaction one would expect for a patrilinear revolution. Even the Syair notes that Zainal Abidin had the consent of all fourteen Menteri before he set out to claim the Sultanate by force. That the planned attack would indeed have been in defense of matrilinear succession is further suggested by the explicit mention of the maternal nephews of the Menteri Empat Belas who took up arms together with them: "Setelah sudah bicara dan rasan / kumpullah Menteri dengan anak kemanakan / memigang senjata bebilang tangan / negeri Mukomuko hendak dilanggarkan. ${ }^{46} \mathrm{Had}$ the conflict of succession only been one between two sons of the Sultan, the Menteri Empat Belas would hardly have bothered. What difference would it have made to them if the apparently unpopular Zainal Abidin would have been replaced by a younger brother or half-brother? But if, as I suggest, the Sultan did try to make a son instead of a maternal nephew his successor, the Menteri's own interests would have been touched. As a matter of fact, their reaction follows precisely the pattern of the conflict of succession of 1728, when the Menteri Empat Belas killed Sultan Kecil Muhammad Syah for installing his own son as his successor. It is only the swift reaction of the British, who sent a force under Captain Hamilton to protect Sultan Pasisir Barat Syah, that prevented the Menteri from killing him.

In matrilineal societies like Anak Sungai in the eighteenth century, the mother's brother is, in his social functions, more important than the father. I have mentioned that the British agents never understood matriliny. But it is still a striking fact that the British sources completely fail to address the central role of the relationship between maternal uncles (mamak) and sororal nephews (kemanakan) in Anak Sungai society. They don't even mention these kin terms. In their discourse about descent there is only room for fathers and sons. How credible is a representation of descent in a matrilineal

\footnotetext{
43 Ibid., p. 77-81; see also Marsden, The History of Sumatra, pp. 353-54.

44 Kathirithamby-Wells, "The Inderapura Sultanate," p. 83.

45 Hashim et al., The Syair Mukomuko, canto iv, p. 47.

46 "Following the secret discussion, the Menteri gathered with the anak kemenakan, each armed with a weapon, intent upon atacking negeri Mukomuko." Hashim et al., The Syair Mukomuko, canto vi, 38, pp. 5051.
} 
society that uses exclusively agnatic terms? It can certainly not be taken at face value. In making sense of these representations, the authors' ignorance and interest have to be taken into account. I don't think that the British were merely ignorant of the rules of descent in the Anak Sungai Sultanate. Rather I believe that if they consistently wrote only about sons instead of sons and nephews, this was part of the symbolic violence they used to further their interests, which consisted in isolating the circumscribed patriclan of the Sultan from the rest of the local elite, the Menteri Empat Belas.

The Syair itself is no less apt at using this kind of symbolic violence. Composed by the son-in law of Sultan Khalifatullah Inayat Syah during the late years of his reign, it should be seen as one effort to legitimize his rule and to confirm the new principle of patrilinear succession. To achieve this aim it repeatedly stresses the "distinguished descent" of the ruler, ${ }^{47}$ represents previous successions as passing from father to son, and depicts the conflict of succession of 1787-89 as a conflict within a patrilineage. Calling both Zainal Abidin, the nephew of the old Sultan, and the latter's son Tuan Sutan Takdirullah, "eldest son," the Syair creates a typical confusion that is caused by, and intended to accomplish, the total suppression of the principle of succession from maternal uncle to sororal nephew. The editors of the Syair Mukomuko try to explain this inconsistency by emending the translation to say that Tuan Sutan Takdirullah was the ruling Sultan's eldest son by a second wife, while Zainal Abidin was the eldest son by his first wife-an assumption for which there is no evidence. ${ }^{48}$ Alternatively, they suggest that calling the successor "eldest son" was an honorific for Tuan Sutan Takdirullah, who should not be represented as having superseded his elder brother.

In making my own interpretation, I am thus reading against the grain of patrilineal representation in the Syair's narration, drawing on such inconsistencies and logical flaws to support my claims. Perhaps the most obvious inconsistency in the account of the Tuanku Mudo's rebellion is that he should have had very little cause at all to stand up against the Sultan, since he was the heir apparent and the Sultan was already old (he died two years into the rebellion, after a rule of thirty-seven years). Only the overriding of succession principles on the part of the Sultan and the British would have been a reasonable motive for him to overthrow the Sultan.

There were others with a more pressing interest in provoking a conflict over succession in Anak Sungai: the EIC's local agents and their superiors at Bengkulu. After the EIC's west Sumatra territories were reduced from a presidency to a residency just two years previously they lost annual finances close to $£ 38,000$. $^{49}$ In their sudden and desperate need for money they chose to remove their successful competitor in private trade, Zainal Abidin, by first trying to push him out of business through a variety of means and then by instigating the Sultan to disinherit him by switching to patrilinear succession, thus forcing the legitimate heir apparent into rebellion.

The editors of the Syair fail to address this deeper cause of the disturbances in Anak Sungai. The fact that these disturbances continued for more than twenty years, until the death of Zainal Abidin's main ally, Pemuncak Pamanaka Sutan of Pangkalan Jambu in 1811, reflects continuing turmoil within Anak Sungai as a consequence of the patrilineal revolution that had deprived the Menteri Empat Belas of their power at court. The new Sultan felt particularly threatened when the highland alliance burnt

${ }^{47}$ Hashim et al., The Syair Mukomuko, canto x, 68-70, p. 58.

${ }^{48}$ Hashim et al., The Syair Mukomuko, pp. 19, 96 FN 1.

49 Bastin, The British in West Sumatra, p. 84. 
down villages close to Ipuh, in $1804 .{ }^{50}$ It was he who asked the British to assist himand he did not ask the Menteri Empat Belas for help. The British complied once more, defeating the "rebels" in Sungai Tenang the following year. But only after the ultimate demise of the highland alliance in 1811 could the Sultan really feel secure. ${ }^{51}$ It is in my opinion no coincidence that the Syair was composed by the ruling Sultan's son-in-law, Raden Anom Zainal Abidin, at this very moment when Sultan Khalifatullah Inayat Syah's patrilineage triumphed. ${ }^{52}$

The introduction of the patrilinear succession principle in the Sultanate of Anak Sungai thus had immediate causes that had nothing to do with religion. But the reformist movements of the last quarter of the eighteenth century, which promoted the introduction of the shariah, and which originated in the coastal regions, ${ }^{53}$ certainly gave legitimacy to such an endeavor. Indeed, Sultan Khalifatullah Inayat Syah of MukoMuko is praised in the Syair Mukomuko for embracing the religious reforms: "... strict in his duties towards the Muslim brotherhood he enforced the religious law throughout the negeri." ${ }^{\prime 54}$ On the whole, Anak Sungai's shift to patrilinear succession was part of a long-term tendency, first observed by Wilken at the end of the nineteenth century, that indicated formerly matrilineal Malay societies of Sumatra, especially in the coastlands, were losing their "matriarchal" structure due to outside influences. 55

As we have already seen, Zainal Abidin's mother accompanied him on his flight from the British. Perhaps more precisely, and according to matrilinear practice as well as concepts of inheritance and legitimacy, one should say that she accompanied his sister, Tenku Putri, who had married Pamanaka Sutan of Pangkalan Jambu and who might eventually become the mother of the next heir apparent of the legitimate Sultan of Anak Sungai. The younger brothers of Zainal Abidin, Sutan Sidi and Sutan Assin, came along as well, enhancing the number of maternal uncles of the future Sultan and completing the core of the royal matriclan that started its trek across the Barisan to the gold mines of Pangkalan Jambu. All in all ninety people joined Zainal Abidin's party, including his own wife and children. ${ }^{56}$ These latter eventually ended up staying on the coast. Obviously, matrilinear ties superseded the attachment to husband and father in their case as well.

\section{The Highland Alliance}

What the British at the time called "rebels" were in fact a number of powerful highland chiefs, among them Pemuncak Pamanaka Sutan, Tuanku Mudo Zainal

50 Hashim et al., The Syair Mukomuko, p. 21.

51 Hashim et al., The Syair Mukomuko, p. 10.

52 The original manuscript of the Syair was written between 1810 and 1816. The editors argue that the death of the youngest daughter of the Sultan was not only the occasion for composing the Syair, but also its subject proper, while its historical parts are merely introductory. Hashim et al., The Syair Mukomuko, pp. 23,36 .

53 J. J. de Hollander, Sjech Djilah Eddin: Verhaal van den Aanvang der Padri-Onlusten op Sumatra (Leiden: Brill, 1847).

${ }^{54}$ Hashim et al., The Syair Mukomuko, p. 58, canto x, 69.

55 Georg Alexander Wilken, The Sociology of Malayan Peoples: Being Three Essays on Kinship, Marriage, and Inheritance in Indonesia (New York: AMS Press, 1980), p. 94.

${ }^{56}$ Hashim et al., The Syair Mukomuko, p. 17. 
Abidin and his brothers, and the Depati of Koto Tegoh in Sungai Tenang, who had allied with one another to control the highland Jambi gold trade and increase goldproduction. This becomes evident from the whole plot as it resurfaces throughout the sources. This alliance was a coalition of complementary interests. Its raid on villages close to Ipuh in 1804 and its subsequent defeat at the hands of a British punitive expedition provide glimpses into how these interests intersected at a moment shortly before the alliance began to fall apart.

On February 26, 1805, a battle took place in a swamp on the forested slopes of the volcano Gunung Masurai, close to the village of Koto Tegoh in Sungai Tenang. It opposed three hundred to four hundred armed men from the highlands to a force of the East India Company numbering little more than a hundred. The Sumatrans had blocked the path with huge felled trees and built entrenchments. From here they shot at the enemy. The Buginese soldiers in the service of the EIC had hauled a heavy mortar all the way from the coast over the steep flanks of the Barisan mountains. It proved rather inefficient in the thick of the woods. Yet the battle was soon decided in favor of the better organized foreigners when a number of their troops bypassed the Sumatrans and attacked them from the rear.

It was the first battle in the highlands opposing a European power against Sumatrans. But this historical fact did not give Sungai Tenang any prominence as a goal of colonial expansion. Its short moment in colonial history would be all but forgotten, had not William Marsden included the expedition leader's diary in his History of Sumatra ${ }^{57}$ It had taken the British eighteen years to defeat an alliance of highland chiefs that had in no small measure contributed to the decline of their possessions on the west coast. Yet the main damage the alliance had inflicted upon the EIC hadn't been its raids on west coast villages, but the diversion of the gold trade to the east. And the victory on the battlefield did not reverse this shift.

\section{Pemuncak Pamanaka Sutan of Pangkalan Jambu}

The central figure of the highland alliance was a man referred to in the sources sometimes as "Pa Muncha" or "Pomancha" and sometimes as "Pamanaka Sutan." He is characterized by Barnes as a "powerful Chieftain" who had founded the first permanent settlement in Pangkalan Jambu sometime between 1770 and 1780. It is this settlement, with many others that were subsequently founded in the area, that attracted settlers from the west coast and that contributed to the decline of the pepper plantations under the control of the EIC. Before, the mines had been visited only seasonally. ${ }^{58}$ After being settled permanently by peasant families, Pangkalan Jambu appears to have attracted many professional gold miners from Minangkabau. Until today it stands out as a place with strong Minangkabau influence, made visible by huge waterwheels that lift irrigation water from the river on to the level of the rice fields. Such waterwheels are a familiar sight in Minangkabau, but they occur nowhere else in highland Jambi.

We have no direct information as to where this $\mathrm{Pa}$ Muncha actually came from before he settled at Pangkalan Jambu. But one of his names gives a clue. It is obviously

${ }^{57}$ Hastings Dare, "Expedition to the Serampei and Sungei-tenang Countries," reproduced in William Marsden, The History of Sumatra, pp. 308-324.

${ }^{58}$ Kathirithamby-Wells, Thomas Barnes' Expedition, pp. 64-65. 
the misspelled title Pemuncak. In highland Jambi, the heads of a federation were sometimes called Pemuncak. ${ }^{59}$ The title was also frequently used in the Minangkabau heartland, albeit as a mere ceremonial title or gelar, not referring to a head of federation. ${ }^{60}$ In Sungai Tenang, too, the head of the encompassing federation had the title Pemuncak, before the Dutch, in the course of a sweeping standardization of selfrule principles, replaced it with the title Pasirah. The local specificity of the title as a prestigious honorific makes it highly probable that Pamanaka Sutan was a local chief who had moved to the nearby gold-mining area.

This Pemuncak was married at least three times. By his first wife he had two sons, Raja Brahim and Sutan Tukada Ullah. We don't know if they were ever allies of their father, but after the death of their father they appear to have turned against the remaining allies, Zainal Abidin's younger brothers Sutan Assin and Sutan Sidi. That the Pemuncak's own sons should not have endorsed their father is not surprising in matrilinear highland Jambi. His later marriages especially may have estranged his first wife's kin-group, and along with them his own sons. These later marriages were to Zainal Abidin's sister Tenku Putri, as we already know, and to a daughter of the Depati of Koto Tegoh. Both these marriages provided him with strong and committed allies. He needed them to promote immigration from the west coast to his settlement at Pangkalan Jambu-by force, if necessary, but perhaps initially also by using ties of kinship and loyalty of west coast inhabitants to the legitimate Sultan of Anak Sungai. He needed these followers to grow rice and vegetables to have ample food supplies, a fundamental condition if one hoped to attract permanently large numbers of miners and traders.

Everything indicates that the Pemuncak Pamanaka Sutan was the one man who held the highland alliance together, and that it fell apart after his death around 1811. Its breakdown becomes apparent in the fact that the hostilities with the west coast, its favorite cause, came immediately to a halt after $1811 .^{61}$

The settlements at Pangkalan Jambu seem to have grown throughout the nineteenth century. By the end of the century, the center of power as well as the toponym "Pangkalan Jambu" had moved downriver, closer to Muara Mesumai, the present-day Bangko. Here was the home of the powerful Pengeran Temenggung, the most important ally of Sultan Taha of Jambi during his long exile and war against the Dutch. He ruled over all federations along the Merangin and Mesumai, from Kerinci almost to the confluence of the Merangin with the Tembesi at Pauh. ${ }^{62}$

\section{The Depati of Koto Tegoh}

The second strong figure in the alliance was the Depati of Koto Tegoh. We know of him only through the report of Hastings Dare, where he is called a "principal instigator of the disturbances. ${ }^{\prime \prime 3}$ He must have joined the alliance some time after

\footnotetext{
${ }^{59}$ R. C. van den Bor, "Aanteekeningen betreffende bestuursvorm en rechtspraak in de Boven-Tembesi tijdens het Sultanaat van Djambi," Tijdschrift voor het Binnenlandsch Bestuur XXX (1906): pp. 431-465, esp. p. 437; Rapp, Resultaten van het onderzoek, pp. 18-20.

60 Dobbin, Islamic Revivalism, p. 208.

61 Hashim et al., The Syair Mukomuko, p. 21.

62 Rapp, Resultaten van het onderzoek, p. 1.

63 Dare, "Expedition to the Serampei and Sungei-tenang Countries," p. 321.
} 
1789; since had he already become the Pemuncak's father-in-law by that time, he certainly would have helped Zainal Abidin, the Pemuncak's brother-in-law, after his flight from Muko-Muko. Zainal Abidin might rather have taken refuge with his relation in Koto Tegoh instead of in nearby Serampas, where he soon overstayed his welcome, eventually killing two of his hosts. It is therefore likely that the Depati of Koto Tegoh joined the alliance only after Pemuncak Pamanaka Sutan and Zainal Abidin had united in Pangkalan Jambu and from there started their raids on the west coast.

The Depati of Koto Tegoh's personal interests in taking part in the raids on the west coast are not at all evident. After the decline of the gold trade across the Barisan, of which he controlled a strategic bottle-neck, he may have sought alternative sources of wealth. He may have had a personal motive in strengthening his leadership by having a large number of dependents who could work for his household and who, maybe, could engage in some sort of commercial activity, like growing cassia for sale or digging for gold in his son-in-law's mines. Or he may have sold his share of the enslaved west-coast people. We do know that after the battle of 1805, the chiefs of Sungai Tenang returned the Depati of Koto Tegoh's share of the abducted villagers to the west coast, thus renouncing any profit that had accrued to them through the alliance. $^{64}$

His political motives are more obvious. It is likely that the Depati of Koto Tegoh had taken the initiative in a political situation that forced all of Sungai Tenang and Serampas into the arms of the alliance. The shift of highland trade from the west coast to the east coast had strong implications for these areas that lie astride the Barisan. It meant that the trade routes linking the gold-producing areas along the Limun and of Batin Pengambang along the Batang Asai to the markets of Muko-Muko and Indrapura became deserted, and only local people would use them further to bring essential goods into their highland villages. Therefore the need to maintain and pacify the route became a local affair, too, and no alliance with a strong outside partner would facilitate the endeavor.

Sungai Tenang's involvement with the highland alliance of Pangkalan Jambu was thus a consequence of these changed circumstances. During the heyday of the "rebel" alliance, between about 1790 and 1811, the chiefs at Pangkalan Jambu used the route through Sungai Tenang and Serampas for slave-raiding on a part of the west coast where they had nothing to lose in terms of business connections. These raids thus ultimately reflect the reorientation of highland Jambi's trade-relationships towards the east coast of Sumatra and the Straits of Malakka. For the people of Sungai Tenang, participation in these raids was a political, not an economic necessity, for, having lost their economic clout as controllers of a trade route, they had to avoid being sacked themselves. Apart from the Depati of Koto Tegoh and his immediate followers, the inhabitants of Sungai Tenang and Serampas were probably rather reluctant partners of the alliance, and their overall attitude may have been disapproval of the raids, since they made it difficult for highland people to frequent the markets on the west coast. Two circumstances reflect this reluctance. First, the people of Serampas readily assisted Hastings Dare while he prepared his assault on the alliance. ${ }^{65}$ The memory of Zainal Abidin killing two Depati of Serampas in 1789 certainly contributed to their friendly

${ }^{64}$ Hashim et al., The Syair Mukomuko, p. 21.

65 Dare, "Expedition to the Serampei and Sungei-tenang Countries," p. 318. 
114 Heinzpeter Znoj

attitude. Secondly, it seems likely from Hastings Dare's account of the speedy conclusion of a peace treaty between the EIC and Sungai Tenang, that the inhabitants of Sungai Tenang were in fact relieved at the course of events. ${ }^{66}$

The outcome of the whole affair for Sungai Tenang is difficult to guess, since no known sources have survived, and there are also no oral accounts. According to Dutch sources, Muko-Muko again became, after its demise in the final decades of EIC rule, and after the Dutch reduced the role of the Sultan, a very important market for the interior. From the 1830s until the end of the nineteenth century, it attracted traders from as far as Batang Asai, Limun, Pangkalan Jambu and Kerinci. ${ }^{67}$ It thus appears that after an interlude of several decades highland Jambi's trading preferences reverted to what they had been before the revolt of Tuanku Mudo Zainal Abidin. Old people in Sungai Tenang still remember the narratives of their parents and grandparents relating that up to the turn of the twentieth century, before there were safely accessible markets in Kerinci, Bangko and Sarolangun, it was to Muko-Muko that people turned to buy and sell.

\section{Tuanku Mudo Zainal Abidin and His Brothers}

The third central figure in the alliance, and the one most familiar to us, was the heir apparent of the Sultanate of Anak Sungai, Tuanku Mudo Zainal Abidin. When the attack on the villages close to Ipuh took place in 1804, he had been dead for about six years, and it was his younger brothers Sutan Assin and Sutan Sidi who were the partners of the Pemuncak and the Depati of Koto Tegoh.

As we have seen, Zainal Abidin had started his alliance-building in the highlands even before he had broken with the Sultan and the EIC. The marriage of his sister Tenku Putri to Pamanaka Sutan is enough evidence for this. Immediately after the outbreak of the conflict he sought allies in Serampas and later in Tapan and Pulo Sangkar along the way from Kerinci to Indrapura. ${ }^{68}$ Later the alliance was extended to Sungai Tenang and may at one point even have included the gold-producing areas of Batang Asai. It is conceivable-and as we are speaking of individuals engaged in the gold trade, which is so sensitive to security of trade routes, even likely-that at its peak the alliance was an important part of a wider network of alliances throughout the tributaries of the Batang Hari and perhaps even the Indragiri and the Musi, which secured a lively trade completely outside the control of the coastal Sultanates and European trading companies. The marriage of Zainal Abidin's younger brother Sutan Sidi in Jambi town can be seen as a move to secure a privileged outlet for Pangkalan Jambu's gold at that port. Zainal Abidin's immediate motive for fostering the alliance therefore appears to have been the control of gold trade, but he certainly shared Pamanaka Sutan's interest in making Pangkalan Jambu great by attracting more people.

Zainal Abidin's move, some time after his defeat in Anak Sungai, to Pangkalan Jambu, the then most important source of gold in highland Jambi, follows a familiar pattern in Sumatran history. Like many a rebellious heir apparent of a downstream

66 Dare, "Expedition to the Serampei and Sungei-tenang Countries," p. 322.

67 T. C. Bogaard, "Moko-moko in 1840" Bijdragen tot de Taal-, Land-en Volkenkunde van Nederlandsch-Indië VI (1858): 26-42; Francis, "Benkoelen in 1833."

${ }^{68}$ Kathirithamby-Wells, Thomas Barnes' Expedition, p. 65. 
ruler, he located himself close to the upstream sources of wealth and helped divert the flow of upstream goods to a different port. Obviously, he now played on the good strategic position of Pangkalan Jambu, whose produce was vied for by the Sultan of Jambi (the nominal owner of the mines), by the Dutch in Indrapura, the British in Muko-Muko, and by the private traders in Penang. Penang attracted much business by the end of the nineteenth century, and Sumatra's gold was in high demand there. As Dobbin notes, Penang supplied many small east coast ports-Jambi among otherswith goods. ${ }^{69}$

Yet in Zainal Abidin's case, the shift of the locus of enterprise from the coast to the interior reflects something more than the upstream-downstream dynamic, since it is at the same time a shift from mercantile control of flows of trade to control and development of the production site itself. Even if it took place under chaotic circumstances, and initially against the will of the Tuanku Mudo himself, it is nevertheless a perfect example of what happened in the whole of central Sumatra at the time, from Minangkabau down to the Bengkulu coast. In the 1780s, pepper growing became a desperate concern on the Bengkulu coast, and also on the Dutchcontrolled west coast further north, as a free-trade regime in Aceh and Penang started to drive pepper prices down. ${ }^{70}$ The pepper growers of the immediate hinterland on the west coast lost their purchasing power. At the same time, highland products like cassia, coffee, and gambir became more frequently traded. This shift in products and production sites went hand in hand with the migration back to the highlands of part of the coastal population that had previously settled there because of the pepper boom.

As we have seen, these population movements often took the form of so-called "slave" raids. I am reluctant to use this word without qualification. As Anthony Reid has argued, for poor peasants in Southeast Asia in historical times, "security and opportunity depended upon being bonded to somebody strong enough to look after them. ${ }^{\prime 71}$ For peasant families who were intent on leaving the west coast due to the economic decline there, to move to a more promising place in the highlands was only possible if their survival during the first rice season was guaranteed by somebody able to provide them with land and rice. In return they would be bonded to him, sell him their produce at his terms and work for him for cheap wages. Their bondage certainly meant a loss of freedom. But they may have lost it anyway on the west coast, where at the turn of the nineteenth century the practice of debt-bondage became more and more widespread as did the practice of "escaping" to the highlands.

The alliance of the chiefs of Pangkalan Jambu thus increased the number of dependent peasant families in the vicinity of the gold mines with a system of forced immigration. The abducted villagers were shared among the participants of the raids. Politically, the acquisition of farming followers by many individual mining and trading entrepreneurs led to open competition for power among many contestants, a

\footnotetext{
${ }^{69}$ Dobbin, Islamic Revivalism, p. 93.

70 Dobbin, Islamic Revivalism; Kathirithamby-Wells, The British West Sumatran Presidency; James Siegel, The Rope of God (Berkeley and Los Angeles: University of California Press, 1969).

71 Anthony Reid, "Introduction: Slavery and Bondage in Southeast Asian History" in Slavery, Bondage and Dependency in Southeast Asia (New York: St. Martin's Press, 1983), p. 8.

72 Bastin, The British in West-Sumatra, p. 149; Kathirithamby-Wells, The British West Sumatran Presidency, pp. 107-08; Marsden, The History of Sumatra, pp. 253-54.
} 
116 Heinzpeter Znoj

situation conveyed by Barnes's travel account. ${ }^{73}$ Zainal Abidin at least found himself in politically much more volatile setting than he had known on the west coast under British control. His main assets in the power game at Pangkalan Jambu were his close relationship to the founder of the settlement and his ability to provide it with new immigrants from the west coast.

At the time of Barnes's visit to Kerinci and Pangkalan Jambu in 1818, little was left of this particular alliance. Sutan Sidi and Sutan Assin had left Pangkalan Jambu and lived impoverished in Jambi and some other place further downstream, respectively. ${ }^{74}$ After Zainal Abidin's death in 1798, Sutan Assin may have succeeded his elder brother, and if such a succession indeed took place it is likely to have been endorsed by the Pemuncak, since six years later the two brothers were still his allies. Their interest in moving the populations of at least a few villages from the west coast to Pangkalan Jambu can therefore be seen as the substantiation of their claim to represent the legitimate Sultanate of Anak Sungai. Their raids were mounted with a secure sense of political authority. Yet it is likely that these relocated people did not continue to view themselves as dependents of the Sultan after Sutan Sidi and Sutan Assin had left Pangkalan Jambu, since, according to Barnes, the two had "sold" the relocated peasants. After the loss of the battle of Koto Tegoh in 1805, which had deprived Sutan Sidi and Sutan Assin of their capability to provide large numbers of immigrants from the west coast and after the death of their brother-in-law Pemuncak Pamanaka Sutan around 1811, their political assets at Pangkalan Jambu were greatly reduced. Conceivably, a son of the Pemuncak Pamanaka Sutan and his wife Tenku Putri may have succeeded to the "rebel" title of Sultan of Anak Sungai, after his two mamak or mother's brothers had left behind their dependents. We don't know if such a successor indeed existed, and if he existed, whether he could still claim any dependents. We only know that at the time of Barnes's visit in 1818, Tenku Putri, the Pemuncak's widow, still lived in Birun, a village close to Pangkalan Jambu, together with some eighty people from Ipuh. According to Barnes they all were eager to return to Ipuh but were not allowed to leave. ${ }^{75}$ This suggests that the "rebel" Sultanate of Anak Sungai had by then indeed lost all power over its former dependents. The three remaining siblings lived widely dispersed, sick, poor, old and unrespected-stranded in the failed attempt to save their Sultanate.

However, the Pemuncak's sons, Sutan Tukada Ullah and Raja Brahim, were important chiefs in Pangkalan Jambu, though neither inherited the title Pemuncakwhich is not surprising if one supposes that matrilineal inheritance principles determined the succession to titles. Raja Brahim was the head of the "Padri" with the title Tuanku Malim, while a certain Pangulu Mudo was the principal chief of Pangkalan Jambu. ${ }^{76}$

\section{The Islamic Reform Movement in Pangkalan Jambu}

When the "rebel" alliance crumbled after the death of Pemuncak Pamanaka

Sutan, this was only partly due to the defeat, in 1805, in the battle of Koto Tegoh and

\footnotetext{
${ }^{73}$ Kathirithamby-Wells, Thomas Barnes' Expedition, p. 64.

74 Ibid., p. 65.

75 Ibid., p. 65.

${ }^{76}$ Ibid., pp. 57, 67.
} 
the subsequent loss of their ability to provide new settlers. Other factors also played a part. In particular, we note that a religious movement identical with or akin to the Wahhabi-influenced Padri movement in Minangkabau had made its appearance at Pangkalan Jambu around this time, and it is likely that this movement actively brought down what remained of the "rebel" Sultanate and the alliance it was part of.

The Wahhabi-inspired reform movement originated in Minangkabau in the first years of the nineteenth century. The strong immigration of Minangkabau into highland Jambi in the course of the gold boom makes it probable that the movement quickly spread along the main trading routes in highland Jambi. Making this assertion, I disagree with Christine Dobbin, who writes in her book on Minangkabau: "The Padri movement made no impact to the south of the Minangkabau heartland. The adjoining regions of Sungai Pagu and Kerinci, although peopled by Minangkabau, were hilly, isolated and sparsely settled."77 Other scholars have tended to agree with Dobbin's judgment that the Wahhabi or Padri movement of the early 1800 s had little direct impact on highland Jambi. Jeya Kathirithamby-Wells, who edited the most important European early nineteenth-century source on Kerinci, Barnes's travel account of 1818, argues that Barnes's mention of Padri in Kerinci and Pangkalan Jambu refers not to the Padri movement specifically but only vaguely to any religious authority. ${ }^{78}$ She points out that the term "Padri" was in use in Southwestern Sumatra as early as the first quarter of the eighteenth century. ${ }^{79}$ Bickmore mentions three Padri from the area of Danau Kerinci who upon their return from Mecca in 1807 initiated religious reforms. ${ }^{80}$ But Bickmore's story as a whole refers to the developments in Minangkabau and it is therefore doubtful evidence for the Padri movement's presence in Kerinci. ${ }^{81}$

Nevertheless, the sharp changes in daily life in Kerinci which took place between the visits of Campbell in $1800^{82}$ and Barnes in 1818, changes that altered it from a society where men wore colorful dresses and staged frequent festivities and cockfights, while unmarried women would also talk to strangers, to a society where everybody was clad in simple black clothes, festive entertainments like dance, music, drink and gambling were forbidden, and women never appeared in public, testify to the kind of revolution in habitus that was the trademark of the Wahhabi reform movement. It may have reached Kerinci more or less independently of and even prior to parallel movements in Minangkabau. Watson mentions reformist initiatives by the Sultan of Jambi late in the eighteenth century that could have paved the way for a local Wahhabi-inspired reformist movement. ${ }^{83}$ Later in the nineteenth century, there was a reformist Islamic center in Rawang in northern Kerinci that was frequently at war with other villages and that displayed similar characteristics of religious orthodoxy. ${ }^{84} \mathrm{On}$

\footnotetext{
77 Dobbin, Islamic Revivalism, p. 161.

${ }^{78}$ Kathirithamby-Wells, Thomas Barnes' Expedition, p. 82, FN 84.

${ }^{79}$ Kathirithamby-Wells, The British West Sumatran Presidency, p. 37.

80 A. S. Bickmore, Travels in the East Indian Archipelago (London, 1868), p. 471.

${ }^{81}$ Kathirithamby-Wells, Thomas Barnes' Expedition, p. 25.

82 Charles Campbell, "Account of the inland Country of Korinchi," reproduced in William Marsden's History of Sumatra (Kuala Lumpur: Oxford University Press, 1975 [1800]) pp. 304-308.

83 Watson, "Islamization in Kerinci," Change and Continuity in Minangkabau, ed. Franz von BendaBeckmann and Lynn L. Thomas (Athens, Ohio: Ohio University Center for International Studies, 1985), pp. 157-79, 162-63.

${ }^{84}$ Watson, "Islamization in Kerinci," pp. 170-71.
} 
118 Heinzpeter Znoj

the other hand, in the southern parts of Kerinci, there are late nineteenth-century sources that describe a strong adherence to the old local animist and ancestral cults, and widespread Islamic reforms occurring only in the last decades of the century. ${ }^{85}$ In short, at least parts of the Jambi highlands experienced the same repeated waves of religious reform that took place simultaneously in the highlands of Minangkabau. ${ }^{86}$ Even if it wasn't exactly the same movement as in Minangkabau, it would have been a very similar movement that arose out of similar causes.

There is a debate about the specific causes that led to the revolutionary religious changes and political upheavals in the highlands of central Sumatra around the turn of the nineteenth century. Christine Dobbin offered an explanation based on the coincidence of these movements with the establishment of widespread cash-cropping for export. Trade in these cash crops necessitated a new commercial code of conduct and economic discipline, both of which were eventually found in Islamic rules and practice. ${ }^{87}$ She describes how the Minangkabau highlands in particular experienced an economic boom due to the cultivation of such export crops as cassia, coffee, and gambir. According to Dobbin, this boom was accompanied by the establishment of a new regime of small-scale production and trade, independent of and in competition to the court system that had evolved around the exploitation of the gold mines. This older highland economy had included a regional division of labor and an elaborate market system in which such essentials as iron, rice, and cloth were produced and traded. The royal family had dominated and secured the gold trade, which supplied the internal market of the highlands with imported goods. The expansion of cash-crop production rendered the acquisition of imported wealth independent of gold trade, and, hence, more democratic in principle. A new class of small-scale traders arose that wanted to get rid of the court system and the costly prestige consumption attached to it, which had impeded free trade. Islam offered a code of commercial conduct that could solve the regulatory crisis that such widespread commercialization brought about. In the absence of a supra-village enforceable contract-law, the shariah offered a viable alternative to the established system. According to Dobbin, the success of Islamic reformist movements among the small traders and cash-crop producers of the highlands during the boom years of free trade at the turn of the nineteenth century, as well as the concomitant decline of the court system, testify to the popularity of at least the economic changes offered by strict adherence to Islamic principles.

Bill Watson, in contrast, makes the good point that it is hard to imagine that the Minangkabau did not have a viable commercial code before they adopted Islamic rules of conduct. As evidence he cites traditional maxims governing property and trading practices. ${ }^{88}$ Moreover, one can argue alongside Watson that the Wahhabi reformers did not restrict themselves to the regulation of small-scale trade financed by the new cashcrops. They made it a point of special interest to control and reform the gold mines, which had not only given rise to the court system but were also a hotbed of animist beliefs and practices that had to be repressed. And finally, as was the case for Imam Bonjol, the most famous and successful leader of the Padri, they profited from the

\footnotetext{
85 Ibid., p. 172.

86 Taufik Abdullah, Schools and Politics: The Kaum Muda Movement in West Sumatra (1927-1933) (Ithaca: Cornell Modern Indonesia Project, 1971), pp. 6-7.

87 Dobbin, Islamic Revivalism.

88 Watson, "Islamization in Kerinci," p. 161.
} 
mines in the same manner as had the court of Pagar Ruyung. ${ }^{89}$ Watson points to the fact that Islam offered venues of prestige for men who were excluded from fast ascent to higher social status due to their age and position in the local clans. In a booming commercial situation of the kind that existed at the turn of the nineteenth century in the highlands of Sumatra, ambitious individuals, especially industrious young men, could rely more on their own resources and were less tied up in the web of solidarity and social control of their villages and clans than previous generations had been. They could risk living according to their religious convictions, among other things. The Wahhabi movement from Mecca, which was spread to the Sumatran highlands by a few charismatic personalities and which stood in an already long tradition of religious reform, acquired its extraordinary dynamism because such people responded readily to the opportunities it offered. Watson's argument thus tries to make room for a proper dynamic of religious development, while acknowledging the overall importance of economic integration for the process. He favors an explanation based on social changes brought about by the emergence of a class of rich men who were unable to express their power within the political system of inherited authority, and who embraced first the Hajj and from there the Islamic reform movements originating in Mecca as a vehicle for personal prestige. I would add to these economic reasons the mobilization of spiritual resistance against anticipated European intrusion, as I will argue below.

Incidentally, the Rao gold mines close to Bonjol at the northern fringes of Minangkabau offer a closer parallel to the developments in Kerinci and Pangkalan Jambu than does the Minangkabau heartland itself. Bonjol was located strategically between Dutch and British interests in a manner similar to Pangkalan Jambu, and it was equally able to build a regional commercial empire based on the admixture of reformist Islamic policing of trade and the lucrative exploitation of gold mines. As in Bonjol, the Malim at Pangkalan Jambu did not replace all local political leaders, although they certainly tried to dominate them. ${ }^{90}$ Both centers enjoyed a period of prosperity after the Padri had taken over from the local elite. By the time of Barnes's visit, the Islamic leaders had turned Pangkalan Jambu into a major market place that channeled the trade to and from Jambi, Minangkabau, Kerinci, Indrapura and Batang Asai. $^{91}$

Barnes's ill-fated expedition provides us with some insights into the everyday politics of the reform movement. Barnes had received orders from Raffles to cross the island from Indrapura to Jambi. He took the obvious and well-frequented route through Kerinci and along the Merangin, then crossing over into the valley of the Mesumai. He hoped to pass through Pangkalan Jambu and take rafts and boats to Jambi a few days downstream of this place. After a very friendly welcome in Lempur, a group of villages related to Serampas, Barnes's journey was slowed in Pulo Sangkar, not far from Lake Kerinci. Here he met Raja Brahim, the chief of the Padri, and Sutan Tukada Ullah, the sons of the late Pemuncak Pamanaka Sutan, who promised to take him to Pangkalan Jambu, where they lived, and onward further downstream. What followed was a protracted highway robbery during which the two brothers patiently extorted all the cash Barnes carried with him as payment for carriers and duties to village chiefs along the way. Barnes ended up spending one month, and all the money

\footnotetext{
89 Dobbin, Islamic Revivalism, p. 178.

90 For Bonjol see Dobbin, Islamic Revivalism, pp. 161-163.

${ }^{91}$ Kathirithamby-Wells, Thomas Barnes' Expedition to Kerinci, p. 69.
} 
he had left (a total of $£ 800$ ), in Pangkalan Jambu. ${ }^{92}$ On entering the plain of Pangkalan Jambu, Barnes's party was forced by the Padri to cross to the far side of the river in order to pass a mosque; ${ }^{93}$ and later on it was the Padri who vehemently opposed the passage of the Europeans on to Jambi. At the end, it seems as if Raja Brahim and Sutan Tukada Ullah had never intended to lead Barnes's party to Jambi. To the contrary, they seemed determined to make sure that his own troops deserted him and that he would be forced to return to the west coast empty-handed. Barnes of course felt humiliated at the treatment he suffered, and he nursed revengeful fantasies about bringing the highlands under control with a network of military roads. The attitude of the chiefs of Pangkalan Jambu clearly reflects a policy of discouraging the European powers from entering the highlands and a religiously expressed animosity.

This very same combination of religious antipathy and political resistance would motivate the Padri movement in Minangkabau to wage a long-lasting war against the Dutch invaders a few years later. And these responses were at the heart of the Aceh war in the last third of the nineteenth century, and of the anti-Dutch movements in highland Jambi at the turn of the twentieth century, led by Sultan Taha, and again in 1916, during the Serikat Abang rebellion. ${ }^{94}$ I think it is no coincidence that all these religious movements in the highlands took place in areas the colonial powers had started to single out as the prizes of Sumatra. They have, in my opinion, to be understood in part as spiritual resistance movements genuinely directed against the European colonialists. If one perceives them as reactions to the projection of European power, it is surely not astonishing to find that the Islamic movements in the highlands were strongest where the interest of the Europeans were strongest too. When the reformists created Islamic "fortresses" against European expansion in the centers of trade and market-production, it was not so much because they had to give themselves an Islamic code of commercial conduct, as Dobbin argues, but because these were the places most in need of protection from European conquest. The European desire to enter the highlands, which became stronger with the decline of the west coast economy, did not go unnoticed in the highlands. It provoked a spiritual mobilization against this European ambition long before the Europeans physically conquered the highlands.

\section{Conclusion}

More broadly, the information that a reform movement akin to that of the Padri movement did indeed reach the Jambi highlands, and in particular the gold mines of Pangkalan Jambu, sheds some light on later historical developments. Christine Dobbin has shown that the old Padri villages in Minangkabau continued to be at the forefront of Islamic developments up to the twentieth century and that they also played important roles in the mobilization of political resistance against the Dutch and indeed in the struggle for Indonesian independence. ${ }^{95}$ The same may be true for the southern part of Central Sumatra, the Jambi highlands. It would then not be so surprising to find

\footnotetext{
92 Ibid., pp. 47, 63.

93 Ibid., p. 55.

94 Taufik Abdullah, Reaction to the Expansion of Colonial Power: The Jambi Experience in Comparative Perspectives (s.l.: Lembaga Ekonomi dan Kemasyarakatan Nasional, 1981).

95 Dobbin, Islamic Revivalism, p. 242.
} 
Kerinci at war with Dutch conquerors at the beginning of the twentieth century. Nor would it be a shock to discover that the area downstream of Pangkalan Jambu and along the Tembesi and the Batang Asai had been engaged in fierce resistance against the Dutch, first in a long guerrilla war at the side of Sultan Taha at the end of the nineteenth century, and later in the Serikat Abang rebellion of $1916 .{ }^{96}$

Other areas in the highlands, like Serampas and Sungai Tenang, were situated outside the main trade routes, and so were untouched by the influence of the Wahhabi movement during the first decades of the nineteenth century. Dutch witnesses of the state of Islamic practices at the turn of the twentieth century suggest that this particular brand of Islamic reformism had at least left no lasting impression there. ${ }^{97}$ These areas also never took part in anti-Dutch resistance movements. The particular geography of resistance to Dutch rule in Jambi at the turn of the twentieth century is therefore ultimately linked to the existence of a web of strong alliances that controlled the gold trade in highland Jambi since the end of the eighteenth century and that came under the influence of an equally strong religious reform movement shortly after 1800 .

Tuanku Mudo Zainal Abidin's rebellion against the British was one of the narratives that nursed a spirit of resistance against the Europeans in highland Jambi. The Wahhabi-inspired movement reinforced it with a strong sense of Islamic identity. And the arrival of the Dutch in the highlands in 1901 was the long-expected event that called for the mobilization of this spiritually grounded resistance.

96 J. C. Kielstra, "Djambi en de Sarekat Islam" Tijdschrift voor Economische Geographie VII (1916): 537-541; Tideman, Djambi, pp. 41-42.

97 Anonymus "Krijgsverrichtingen van 1900-1904 in de residentie Djambi" Sumatra's Westkust microfiche no. 269 (Jambi: Memorie van Overgabe, 1904); E. A. Klerks, "Geographisch en Ethnographisch Opstel Over de Landschappen Korintji, Serampas en Soengai Tenang" Tijdschrift voor Indische Taal-, Land en Volkenkunde 39 (1897): 1-114. 